\title{
Varietal Performance of Turmeric under Mango Based Agroforestry System
}

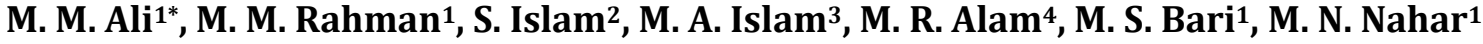 \\ ${ }^{1}$ Department of Agroforestry and Environment, Hajee Mohammad Danesh Science and Technology University, Dinajpur, \\ Bangladesh \\ ${ }^{2}$ Advanced Seed Research and Biotech Centre, ACI Limited, Dhaka, Bagladesh \\ ${ }^{3}$ Department of Agriculture Extension, Hajee Mohammad Danesh Science and Technology University, Dinajpur, Bangladesh \\ ${ }^{4}$ Department of Plant Breeding, Hajee Mohammad Danesh Science and Technology University, Dinajpur, Bangladesh \\ Email: *manikhstu49@gmail.com
}

How to cite this paper: Ali, M.M., Rahman, M.M., Islam, S., Islam, M.A., Alam, M.R., Bari, M.S. and Nahar, M.N. (2018) Varietal Performance of Turmeric under Mango Based Agroforestry System. American Journal of Plant Sciences, 9, 995-1003. https://doi.org/10.4236/ajps.2018.95076

Received: December 13, 2017

Accepted: April 17, 2018

Published: April 20, 2018

Copyright $\odot 2018$ by authors and Scientific Research Publishing Inc. This work is licensed under the Creative Commons Attribution International License (CC BY 4.0).

http://creativecommons.org/licenses/by/4.0/

c) (i) Open Access

\begin{abstract}
An experiment was carried out at the Agroforestry and Environment Research Farm, Hajee Mohammad Danesh Science and Technology University, Dinajpur, Bangladesh, during April, 2014 to January 2015. The experiment was laid out in two factors Randomized Complete Block Design (RCBD) with three replications. Among the two factors, one factor like A was two production systems: $S_{1}=$ Mango + Turmeric and $S_{2}=$ Turmeric (sole crop); another factor like $\mathrm{B}$ was three turmeric variety: $\mathrm{V}_{1}=$ BARI Holud-1, $\mathrm{V}_{2}=$ BARI Holud-2 and $\mathrm{V}_{3}=$ BARI Holud-3. So, the treatment combinations were: $\mathrm{S}_{1} \mathrm{~V}_{1}=$ Mango + BARI Holud-1, $\mathrm{S}_{1} \mathrm{~V}_{2}=$ Mango + BARI Holud-2, $\mathrm{S}_{1} \mathrm{~V}_{3}=$ Mango + BARI Holud- $3, \mathrm{~S}_{2} \mathrm{~V}_{1}=$ sole cropping of BARI Holud- $1, \mathrm{~S}_{2} \mathrm{~V}_{2}=$ sole cropping of BARI Holud-2 and $\mathrm{S}_{2} \mathrm{~V}_{3}=$ sole cropping of BARI Holud-3. The result of the experiment revealed that interaction effect of production systems and variety was found significant on plant height, number of leaf per plant, length of leaf blade, breadth of leaf blade, number of finger per rhizome, fresh and dry yield per hectare. The higher fresh yield of turmeric (34.75 t/ha) and dry yield (6.10 t/ha) was found from $S_{1} V_{1}$ treatment (Mango + BARI Holud-1). Whereas the lowest fresh yield (33.41 t/ha) and dry yield (4.93 t/ha) was found from $\mathrm{S}_{2} \mathrm{~V}_{2}$ treatment (sole cropping of BARI Holud-2). However, the suitability of the cultivation of different turmeric variety under mango based agroforestry systems may be ranked as $\mathrm{S}_{1} \mathrm{~V}_{1}>\mathrm{S}_{2} \mathrm{~V}_{1}>\mathrm{S}_{1} \mathrm{~V}_{3}>\mathrm{S}_{2} \mathrm{~V}_{3}>\mathrm{S}_{1} \mathrm{~V}_{2}>\mathrm{S}_{2} \mathrm{~V}_{2}$. Finally it may be concluded that, BARI Holud-1 would be the best variety to be grown under mango based agroforestry.
\end{abstract}

\section{Keywords}

Turmeric, Mango, Suitability, Agroforestry System, Varieties, Sole Cropping 


\section{Introduction}

Turmeric is very important spices as well as a medicinal plant in Bangladesh. Common Bangladeshi people traditionally use various spices in curry in their daily life. Among them, turmeric (Curcuma longa) is the most important one. Besides making curries, it is also used for medicine as a carminative and aromatic stimulant to the gastrointestinal tract [1] and many other purposes. In addition, turmeric is a high valued crop having good local as well as export potentials [2]. But total production of turmeric is 117 thousand metric tons from 21.41 thousand hectors land [3]. The demand of turmeric for home consumption is increasing day by day with the over increasing population of Bangladesh and their demand is worldwide also increasing. Tropics and subtropics provided that rainfall is adequate or facilities for irrigation are available. It is usually grown in regions with an annual rainfall of $1000-2000 \mathrm{~mm}$. But its' cultivation has been extended into moist areas with rain above $2000 \mathrm{~mm}$ per annum. It can be grown up to an altitude of $1220 \mathrm{~m}$ in the Himalayan foothills [1]. Turmeric has been traditionally known as shade loving spices crops of Bangladesh. These spices crops are grown under partial shade condition but their degrees of shade tolerance and which variety is good under shade have not yet been standardized from the scientific point of view.

Again, mango is the king of oriental fruits belongs to the genus Mangifera of the family Anacardiaceae. The genus Mangifera contains several species that bear edible fruit. Mango has become naturalized and adapted throughout the tropics and subtropics. Mango plays an important part in the diet and cuisine of many diverse cultures. This delicious fruit is particularly rich in nutrients such as protein, vitamin A, fiber, thiamine, ascorbic acid etc. The fruit is eaten as green, processed pickles, pulps, jams and is frozen or dried. Mango trees are usually between 3 and $10 \mathrm{~m}(10-33 \mathrm{ft})$ tall but can reach up to $30 \mathrm{~m}(100 \mathrm{ft})$ in some forest situation. The canopy is evergreen. Mango trees are recognized as national tree of Bangladesh, and eaten throughout the world. Mango covered 78,196 acres area under garden having total production of 304,187 metric tons in 2007-2008 [4]. Now a day's turmeric is grown in association with mango by farmers but without much scientific consideration. Many modern varieties of turmeric have been released by Spices Research Centre, BARI in Bangladesh. But the varietal performance under mango based agroforestry is not tested scientifically. Keeping this view in mind, this research has been conducted on mango based agroforestry system in order to evaluate the performance of three turmeric varieties and identify the best variety under mango based Agroforestry system.

\section{Materials and Methods}

\subsection{Experimental Site Description}

The experimental site was selected in the existing Mango orchard of the Agroforestry \& Environment Research Farm, Hajee Mohammad Danesh Science and Technology University, Dinajpur, Bangladesh. The geographical location of the 
site was between $25^{\circ} 13^{\prime}$ latitude and $88^{\circ} 23^{\prime}$ longitude.

\subsubsection{Soil Characteristics}

The experimental plot was situated in a medium high land belonging to the old Himalayan Piedmont Plain area (AEZ 01). Land was well-drained as drainage system was well developed. The soil texture was sandy loam in nature. The soil contains Sand $=65 \%$, Silt $=30 \%$, Clay $=5 \%$, CEC $(\mathrm{meq} / 100 \mathrm{~g})=8.07, \mathrm{pH}=5.35$, Organic matter $=1.06 \%$, Total nitrogen $=0.10 \%$, Sodium $(\mathrm{meq} / 100 \mathrm{~g})=0.06$, Cal$\operatorname{cium}(\mathrm{meq} / 100 \mathrm{~g})=1.30$, Magnesium $(\mathrm{meq} / 100 \mathrm{~g})=0.40$, Potassium $(\mathrm{meq} / 100 \mathrm{~g})$ $=0.26$, Phosphorus $(\mu \mathrm{g} / \mathrm{g})=24.0$, Sulphur $(\mu \mathrm{g} / \mathrm{g})=3.2$, Boron $(\mu \mathrm{g} / \mathrm{g})=0.27$, Iron $(\mu \mathrm{g} / \mathrm{g})=5.30$ and $\mathrm{Zinc}(\mu \mathrm{g} / \mathrm{g})=0.90$

\subsubsection{Climate}

The experimental site was situated under the tropical climate characterized by heavy rainfall from July to August and scanty rainfall the rest period of the year. In April, May, June, July, August, September, October, November, December 2014 and January 2015 maximum air temperature was $\left(32.8^{\circ} \mathrm{C}, 13.9^{\circ} \mathrm{C}, 33.2^{\circ} \mathrm{C}, 32.0^{\circ} \mathrm{C}\right.$, $32.4^{\circ} \mathrm{C}, 32.0^{\circ} \mathrm{C}, 31.6^{\circ} \mathrm{C}, 28.70^{\circ} \mathrm{C}$, and $\left.27.20^{\circ} \mathrm{C}\right)$ and Minimum $\left(21.1^{\circ} \mathrm{C}, 21.5^{\circ} \mathrm{C}\right.$, $23.2^{\circ} \mathrm{C}, 25.8^{\circ} \mathrm{C}, 26.2^{\circ} \mathrm{C}, 25.0^{\circ} \mathrm{C}, 21.0^{\circ} \mathrm{C}, 19.68^{\circ} \mathrm{C}, 18.45^{\circ} \mathrm{C}$, and $\left.16.10^{\circ} \mathrm{C}\right), \mathrm{RH}$ (83\%, 77\%, 82\%,85\%,84\%,89\%, 90\%, 24.77\%, 23.56\% and $21.65 \%)$ and total Rainfall $(54,213,333,369,466,97,10,5,18$ and $12 \mathrm{~mm})$.

\subsection{Experimental Period}

Duration of the experiential period was from April 2014 to February 2015.

\subsubsection{Seed Collections}

Turmeric rhizome was collected from spices research center, Bangladesh Agriculture Research Institute, Bogra.

BARI Holud-1: Plant height long, life cycle 270 - 280 days, fresh Rhizome weight 400 - $420 \mathrm{~g} /$ plant, number of finger/rhizome 7 - 8, Yield 35 - $40 \mathrm{~T} / \mathrm{h}$.

BARI Holud-2: Plant height medium, life cycle 270- 290 days, fresh Rhizome weight 375 - 380 g/plant, number of finger/rhizome 7 - 8, Yield 30 - 35 T/h, color deep yellow.

BARI Holud-3: Plant height medium, life cycle 270 - 290 days, fresh Rhizome weight 400 - 420 g/plant, number of finger/rhizome 7 - 8, Yield 30 - 35 T/h, color deep yellow.

\subsubsection{Experimental Design}

The experiment was laid out following a two factorial Randomized Complete Block Design (RCBD) with three replications. Total number of experimental plot was 9. The size of each unit plot was $5 \mathrm{~m} \times 5 \mathrm{~m}$. Among the two factors, factor $\mathrm{A}$ was two production systems; $S_{1}=$ Mango + Turmeric, $S_{2}=$ Turmeric on sole cropping. Another factor B was three Turmeric varieties; $\mathrm{V}_{1}=$ BARI Holud-1, $\mathrm{V}_{2}$ $=$ BARI Holud-2, $\mathrm{V}_{3}=$ BARI Holud-3. So there were 6 treatments combinations and these were; $\mathrm{S}_{1} \mathrm{~V}_{1}=$ Mango + BARI Holud-1, $\mathrm{S}_{1} \mathrm{~V}_{2}=$ Mango + BARI Holud-2, 
$\mathrm{S}_{1} \mathrm{~V}_{3}=$ Mango + BARI Holud- $3, \mathrm{~S}_{2} \mathrm{~V}_{1}=$ sole cropping of BARI Holud- $1, \mathrm{~S}_{2} \mathrm{~V}_{2}=$ sole cropping of BARI Holud-2, and $\mathrm{S}_{2} \mathrm{~V}_{3}=$ sole cropping of BARI Holud-3.

\subsubsection{Structural Description of the Treatments}

$1^{\text {st }}$ layer (upper layer): Mango tree, Scientific name: Mangifera indica L., Variety: Amropali, Family: Anacardiaceae, Spacing: $5 \mathrm{~m} \times 5 \mathrm{~m}$, Establishment: 2008, Planting direction: East-West, $2^{\text {nd }}$ layer was turmeric.

\subsubsection{Crop Establishment}

The seed rhizome of turmeric was planted maintaining a row to row distance of $50 \mathrm{~cm}$, a plant to plant distance of $25 \mathrm{~cm}$ and a depth of $10 \mathrm{~cm}$. The weight of each seed-rhizome was of $15-20 \mathrm{~g}$.

\subsubsection{Weeding and Irrigation}

Weeding is done as felt necessary. Ear thing up was done thrice; the first one after 60 , the second one after 90 and the final one after 110 days of planting. Some plants were rotten by water logging condition. This condition was controlled by drainage.

\subsubsection{Application of Manure, Fertilizer}

Recommended doses of fertilizers were used as Urea (N@135 kg/ha), TSP $\left(\mathrm{P}_{2} \mathrm{O}_{5} @ 30 \mathrm{~kg} / \mathrm{ha}\right), \mathrm{MP}\left(\mathrm{K}_{2} \mathrm{O} @ 90 \mathrm{~kg} / \mathrm{ha}\right), \mathrm{Gypsum}(\mathrm{S} @ 10 \mathrm{~kg} / \mathrm{ha})$, Zinc Sulfate (Zn@2 kg/ha), Borax (B@1.5 kg/ha), Cowdung (5 ton/ha).

\subsection{Data Collection}

The heights were measured from the ground level to the tip of the longest shoot at an interval of 30 days starting from 90,120, 150, 180 and 210 DAP. The number of tillers per plant, number of leaves per plant, length of leaf blade and breath of leaf blade data are collected at an interval of 30 days starting from 90, $120,150,180$ and 210 DAP. The number of finger per selected plant was counted at harvest time. The weight of fresh rhizome per selected plant was recorded with the help of a balance at the time of harvest. After harvest, rhizome of 10 selected plants were weighed and dried in an oven for 24 hours at $70^{\circ} \mathrm{C}$ till constant weight. After drying the dry rhizome weighed and mean weight was calculated.

\subsection{Data Analysis}

Data were statistically analyzed using the "Analysis of variance" (ANOVA) technique with the help of computer package MSTAT-C. The mean differences were adjudged by Duncan's Multiple Range Test (DMRT) [5].

\section{Results}

The tallest plant of turmeric $(66.63 \mathrm{~cm}, 83.44 \mathrm{~cm}, 109.40 \mathrm{~cm} 129.10 \mathrm{~cm}$ and $102.8 \mathrm{~cm}$ at 90 DAP, 120 DAP, 150 DAP, 180 DAP and $210 \mathrm{DAP})$ was recorded in $\mathrm{S}_{1} \mathrm{~V}_{1}$ (Mango + BARI Holud-1) treatment combination. On the other hand, 
the shortest plant of turmeric $(49.60 \mathrm{~cm}, 64.53 \mathrm{~cm}, 71.23 \mathrm{~cm}, 94.47 \mathrm{~cm}$ and 68.20 $\mathrm{cm}$ at 90 DAP, 120 DAP, 150 DAP, 180 DAP and 210 DAP) was recorded in $\mathrm{S}_{2} \mathrm{~V} 3$ (Sole cropping of BARI Holud-3) (Table 1). Again, the highest number of tiller per plant (2.33, 2.733 .26 and 4.03, respectively at 90 DAP, 120 DAP, 150 DAP, 180 DAP and 210 DAP) was recorded in $\mathrm{S}_{1} \mathrm{~V}_{1}$ (Mango + BARI Holud-1) treatment and lowest number of tiller per plant $(1.53,1.86,2.43$ and 2.86 at 90 DAP, 120 DAP, 150 DAP, 180 DAP and 210 DAP) was recorded in $\mathrm{S}_{2} \mathrm{~V}_{2}$ (Sole cropping of BARI Holud-2) (Table 1). Consequently, the maximum number of leaves per plant $(8.03,10.03,14.73,15.73$ and 12.03 at 90 DAP, 120 DAP, 150 DAP, 180 DAP, 210 DAP) was recorded in $\mathrm{S}_{1} \mathrm{~V}_{1}$ (Mango + BARI Holud-1) treatment. On the other hand, minimum number of leaves per plant $(6.16,8.16$, $12.13,12.53$ and 9.33 at 90 DAP, 120 DAP, 150 DAP, 180 DAP, 210 DAP) was recorded in $\mathrm{S}_{2} \mathrm{~V}_{1}$ (Sole cropping of BARI Holud-3) treatment (Table 2). Similarly, the longest length of leaf blade of turmeric $(45.83 \mathrm{~cm}, 54.10 \mathrm{~cm}, 62.07 \mathrm{~cm}$, $68.47 \mathrm{~cm}$ and $60.40 \mathrm{~cm}$, respectively at $90,120,150,180$ and $210 \mathrm{DAP}$ ) was recorded in $\mathrm{S}_{2} \mathrm{~V}_{1}$ (Mango + BARI Holud-1) treatment. On the other hand, the shortest length of leaf blade of turmeric $(28.37 \mathrm{~cm}, 38.03 \mathrm{~cm}, 46.87 \mathrm{~cm}, 54.10 \mathrm{~cm}$ and $46.17 \mathrm{~cm}$ at $90,120,150,180$ and $210 \mathrm{DAP}$ ) was recorded in $\mathrm{S}_{2} \mathrm{~V}_{3}$ (Sole cropping of BARI Holud-3) treatment combination (Table 2). Once more, the widest leaf blade of turmeric $(11.03 \mathrm{~cm}, 13.67 \mathrm{~cm}, 16.40 \mathrm{~cm}, 18.80 \mathrm{~cm}$ and 15.13 $\mathrm{cm}$ at $90,120,150,180$ and $210 \mathrm{DAP}$ ) was recorded in $\mathrm{S}_{1} \mathrm{~V}_{1}$ (Mango + BARI Holud-1) treatment. On the other hand, the leaf blade with minimum breadth $(8.067 \mathrm{~cm}, 10.83 \mathrm{~cm}, 13.17 \mathrm{~cm}, 14.97 \mathrm{~cm}$ and $12.57 \mathrm{~cm}$ at 90, 120, 150, 180 and 210 DAP) was recorded in $\mathrm{S}_{2} \mathrm{~V}_{3}$ (Sole cropping of BARI Holud-3) treatment (Table 3). Significantly, the highest number of finger per plant (25.0) was recorded in $\mathrm{S}_{1} \mathrm{~V}_{1}$ (Mango + BARI Holud-1) treatment combination. On the other hand the lowest (16.67) was recorded under $\mathrm{S}_{2} \mathrm{~V}_{3}$ (Sole cropping of BARI Holud-3) treatment (Table 4). Again, the highest fresh weight of rhizome per plant

Table 1. Interaction effect of production systems and turmeric variety on plant height and number of tiller/plant at different DAP.

\begin{tabular}{cccccccccccc}
\hline & \multicolumn{4}{c}{ Plant height } & \multicolumn{5}{c}{ Number of tiller/plant } \\
\cline { 2 - 11 } Treatments & 90 & 120 & 150 & 180 & 210 & 90 & 120 & 150 & 180 & 210 \\
& DAP & DAP & DAP & DAP & DAP & DAP & DAP & DAP & DAP & DAP \\
\hline $\mathrm{S}_{1} \mathrm{~V}_{1}$ & $66.63 \mathrm{a}$ & $83.44 \mathrm{a}$ & $109.40 \mathrm{a}$ & $129.10 \mathrm{a}$ & $102.80 \mathrm{a}$ & $2.33 \mathrm{a}$ & $2.73 \mathrm{a}$ & $3.26 \mathrm{a}$ & $4.03 \mathrm{a}$ & $4.03 \mathrm{a}$ \\
$\mathrm{S}_{1} \mathrm{~V}_{2}$ & $61.17 \mathrm{c}$ & $70.65 \mathrm{c}$ & $86.27 \mathrm{c}$ & $106.50 \mathrm{c}$ & $81.60 \mathrm{c}$ & $1.73 \mathrm{ab}$ & $2.13 \mathrm{ab}$ & $2.56 \mathrm{ab}$ & $3.06 \mathrm{bc}$ & $3.06 \mathrm{bc}$ \\
$\mathrm{S}_{1} \mathrm{~V}_{3}$ & $56.40 \mathrm{~d}$ & $67.30 \mathrm{~d}$ & $83.57 \mathrm{c}$ & $101.40 \mathrm{~d}$ & $74.53 \mathrm{~d}$ & $2.03 \mathrm{ab}$ & $2.33 \mathrm{ab}$ & $2.76 \mathrm{ab}$ & $3.26 \mathrm{bc}$ & $3.26 \mathrm{bc}$ \\
$\mathrm{S}_{2} \mathrm{~V}_{1}$ & $63.37 \mathrm{~b}$ & $77.57 \mathrm{~b}$ & $103.00 \mathrm{~b}$ & $116.10 \mathrm{~b}$ & $95.07 \mathrm{~b}$ & $2.13 \mathrm{ab}$ & $2.53 \mathrm{ab}$ & $3.13 \mathrm{ab}$ & $3.73 \mathrm{ab}$ & $3.73 \mathrm{ab}$ \\
$\mathrm{S}_{2} \mathrm{~V}_{2}$ & $53.73 \mathrm{e}$ & $65.14 \mathrm{de}$ & $78.63 \mathrm{~d}$ & $100.50 \mathrm{~d}$ & $72.40 \mathrm{~d}$ & $1.53 \mathrm{~b}$ & $1.86 \mathrm{~b}$ & $2.43 \mathrm{~b}$ & $2.86 \mathrm{c}$ & $2.86 \mathrm{c}$ \\
$\mathrm{S}_{2} \mathrm{~V}_{3}$ & $49.60 \mathrm{f}$ & $64.53 \mathrm{e}$ & $71.23 \mathrm{e}$ & $94.47 \mathrm{e}$ & $68.20 \mathrm{e}$ & $2.13 \mathrm{ab}$ & $2.53 \mathrm{ab}$ & $2.73 \mathrm{ab}$ & $3.23 \mathrm{bc}$ & $3.23 \mathrm{bc}$ \\
$\mathrm{CV}(\%)$ & 1.52 & 2.11 & 2.15 & 1.92 & 1.43 & 15.38 & 14.53 & 13.38 & 11.02 & 11.02 \\
\hline
\end{tabular}

(Note: Means with similar letter (s) in column of the table do not differ significantly by DMRT at P > 5\% level). 
Table 2. Interaction effect of production systems and turmeric variety on Number of leaf/plant and Length of leaf blade at different DAP.

\begin{tabular}{cccccccccccc}
\hline & \multicolumn{4}{c}{ Number of leaf/plant } & \multicolumn{5}{c}{ Length of leaf blade } \\
\cline { 2 - 11 } Treatments & 90 & 120 & 150 & 180 & 210 & 90 & 120 & 150 & 180 & 210 \\
& DAP & DAP & DAP & DAP & DAP & DAP & DAP & DAP & DAP & DAP \\
\hline $\mathrm{S}_{1} \mathrm{~V}_{1}$ & $8.03 \mathrm{a}$ & $10.03 \mathrm{a}$ & $14.73 \mathrm{a}$ & $15.73 \mathrm{a}$ & $12.03 \mathrm{a}$ & $45.83 \mathrm{a}$ & $54.10 \mathrm{a}$ & $62.07 \mathrm{a}$ & $68.47 \mathrm{a}$ & $60.40 \mathrm{a}$ \\
$\mathrm{S}_{1} \mathrm{~V}_{2}$ & $6.96 \mathrm{~b}$ & $8.83 \mathrm{c}$ & $12.60 \mathrm{c}$ & $13.63 \mathrm{~b}$ & $10.57 \mathrm{bc}$ & $34.67 \mathrm{c}$ & $42.80 \mathrm{c}$ & $52.07 \mathrm{c}$ & $59.33 \mathrm{c}$ & $50.33 \mathrm{c}$ \\
$\mathrm{S}_{1} \mathrm{~V}_{3}$ & $6.73 \mathrm{~b}$ & $8.33 \mathrm{~d}$ & $12.17 \mathrm{c}$ & $13.13 \mathrm{~b}$ & $9.733 \mathrm{c}$ & $31.23 \mathrm{e}$ & $40.63 \mathrm{~d}$ & $49.93 \mathrm{~d}$ & $55.83 \mathrm{~d}$ & $48.77 \mathrm{~d}$ \\
$\mathrm{~S}_{2} \mathrm{~V}_{1}$ & $7.16 \mathrm{ab}$ & $9.56 \mathrm{~b}$ & $14.23 \mathrm{~b}$ & $15.17 \mathrm{a}$ & $11.63 \mathrm{ab}$ & $43.67 \mathrm{~b}$ & $52.23 \mathrm{~b}$ & $60.20 \mathrm{~b}$ & $66.03 \mathrm{~b}$ & $58.23 \mathrm{~b}$ \\
$\mathrm{~S}_{2} \mathrm{~V}_{2}$ & $6.33 \mathrm{~b}$ & $8.53 \mathrm{~cd}$ & $12.20 \mathrm{c}$ & $12.73 \mathrm{~b}$ & $9.333 \mathrm{c}$ & $32.60 \mathrm{~d}$ & $40.03 \mathrm{~d}$ & $49.77 \mathrm{~d}$ & $56.57 \mathrm{~d}$ & $48.47 \mathrm{~d}$ \\
$\mathrm{~S}_{2} \mathrm{~V}_{3}$ & $6.16 \mathrm{~b}$ & $8.16 \mathrm{~d}$ & $12.13 \mathrm{c}$ & $12.53 \mathrm{~b}$ & $9.533 \mathrm{c}$ & $28.37 \mathrm{f}$ & $38.03 \mathrm{e}$ & $46.87 \mathrm{e}$ & $54.10 \mathrm{e}$ & $46.17 \mathrm{e}$ \\
$\mathrm{CV}(\%)$ & 7.72 & 2.81 & 2.06 & 1.65 & 6.22 & 1.58 & 1.64 & 1.37 & 1.00 & 4.8 \\
\hline
\end{tabular}

(Note: Means with similar letter (s) in column of the table do not differ significantly by DMRT at P > 5\% level).

Table 3. Interaction effect of production systems and turmeric variety on breadth of leaf blade of turmeric at different DAP.

\begin{tabular}{cccccc}
\hline \multirow{2}{*}{ Treatments } & \multicolumn{5}{c}{ Breadth of leaf blade } \\
\cline { 2 - 6 } & 90 DAP & 120 DAP & 150 DAP & 180 DAP & 210 DAP \\
\hline $\mathrm{S}_{1} \mathrm{~V}_{1}$ & $11.03 \mathrm{a}$ & $13.67 \mathrm{a}$ & $16.40 \mathrm{a}$ & $18.80 \mathrm{a}$ & $15.13 \mathrm{a}$ \\
$\mathrm{S}_{1} \mathrm{~V}_{2}$ & $9.13 \mathrm{~b}$ & $11.77 \mathrm{~b}$ & $14.87 \mathrm{bc}$ & $16.23 \mathrm{c}$ & $13.20 \mathrm{c}$ \\
$\mathrm{S}_{1} \mathrm{~V}_{3}$ & $8.43 \mathrm{~cd}$ & $11.17 \mathrm{bc}$ & $13.47 \mathrm{de}$ & $15.63 \mathrm{~cd}$ & $12.83 \mathrm{c}$ \\
$\mathrm{S}_{2} \mathrm{~V}_{1}$ & $10.60 \mathrm{a}$ & $13.13 \mathrm{a}$ & $15.37 \mathrm{~b}$ & $18.07 \mathrm{~b}$ & $14.23 \mathrm{~b}$ \\
$\mathrm{~S}_{2} \mathrm{~V}_{2}$ & $8.73 \mathrm{bc}$ & $11.30 \mathrm{bc}$ & $14.07 \mathrm{~cd}$ & $15.57 \mathrm{~cd}$ & $12.87 \mathrm{c}$ \\
$\mathrm{S}_{2} \mathrm{~V}_{3}$ & $8.06 \mathrm{~d}$ & $10.83 \mathrm{c}$ & $13.17 \mathrm{e}$ & $14.97 \mathrm{~d}$ & $12.57 \mathrm{c}$ \\
$\mathrm{CV}(\%)$ & 3.61 & 2.70 & 3.04 & 2.16 & 3.40 \\
\hline
\end{tabular}

(Note: Means with similar letter (s) in column of the table do not differ significantly by DMRT at P > 5\% level).

of turmeric (434.30 g) was recorded in $\mathrm{S}_{1} \mathrm{~V}_{1}$ (Mango + BARI Holud-1) treatment. On the other hand the lowest fresh weight of rhizome per plant of turmeric (356.70 g) was recorded in $\mathrm{S}_{2} \mathrm{~V}_{2}$ (Sole cropping of BARI Holud-2) treatment combination (Table 4). Similarly the highest dry weight of rhizome per plant of turmeric $\left(75.13 \mathrm{~g}\right.$ ) was recorded in $\mathrm{S}_{1} \mathrm{~V}_{1}$ (Mango + BARI Holud-1) treatment. On the other hand the lowest fresh weight of rhizome per plant of turmeric $\left(61.63 \mathrm{~g}\right.$ ) was recorded in $\mathrm{S}_{2} \mathrm{~V}_{2}$ (Sole cropping of BARI Holud-2) treatment combination (Table 4). Consequently, the highest fresh yield (34.75 t/ha) was recorded in $\mathrm{S}_{1} \mathrm{~V}_{1}$ (Mango + BARI Holud-1) treatment and the lowest yield $\left(28.53 \mathrm{t} / \mathrm{ha}\right.$ ) was recorded in $\mathrm{S}_{2} \mathrm{~V}_{2}$ (Table 4). Similar trend was recorded in case of dry yield. The highest dry yield (6.01 t/ha) was recorded in $\mathrm{V}_{1} \mathrm{~S}_{1}$ (Mango + BARI Holud-1) treatment and the lowest yield (4.93 t/ha) was recorded in $\mathrm{S}_{2} \mathrm{~V}_{2}$ (Sole cropping of BARI Holud-2) treatment combination (Table 4). 
Table 4. Interaction effect of production systems and turmeric variety on fresh and dry yield of turmeric $\left(\right.$ tha $\left.^{-1}\right)$.

\begin{tabular}{cccccc}
\hline Treatments & $\begin{array}{c}\text { No. of } \\
\text { finger/plant }\end{array}$ & $\begin{array}{c}\text { Fresh wt. of } \\
\text { rhizome/plant }\end{array}$ & $\begin{array}{c}\text { Dry wt. of } \\
\text { rhizome/plant }\end{array}$ & $\begin{array}{c}\text { Fresh yield } \\
(\mathbf{t} / \mathrm{ha})\end{array}$ & $\begin{array}{c}\text { Dry yield } \\
(\mathrm{t} / \mathrm{ha})\end{array}$ \\
\hline $\mathrm{S}_{1} \mathrm{~V}_{1}$ & $28.00 \mathrm{a}$ & $434.30 \mathrm{a}$ & $75.13 \mathrm{a}$ & $34.75 \mathrm{a}$ & $6.01 \mathrm{a}$ \\
$\mathrm{S}_{1} \mathrm{~V}_{2}$ & $23.33 \mathrm{~cd}$ & $370.00 \mathrm{de}$ & $63.98 \mathrm{de}$ & $30.80 \mathrm{c}$ & $5.11 \mathrm{de}$ \\
$\mathrm{S}_{1} \mathrm{~V}_{3}$ & $24.67 \mathrm{bc}$ & $408.30 \mathrm{bc}$ & $69.68 \mathrm{bc}$ & $32.53 \mathrm{bc}$ & $5.56 \mathrm{bc}$ \\
$\mathrm{S}_{2} \mathrm{~V}_{1}$ & $26.33 \mathrm{ab}$ & $417.70 \mathrm{ab}$ & $72.10 \mathrm{ab}$ & $33.41 \mathrm{ab}$ & $5.76 \mathrm{ab}$ \\
$\mathrm{S}_{2} \mathrm{~V}_{2}$ & $21.67 \mathrm{~d}$ & $356.70 \mathrm{e}$ & $61.63 \mathrm{e}$ & $28.53 \mathrm{~d}$ & $4.93 \mathrm{e}$ \\
$\mathrm{S}_{2} \mathrm{~V}_{3}$ & $21.33 \mathrm{~d}$ & $389.00 \mathrm{~cd}$ & $66.20 \mathrm{~cd}$ & $31.12 \mathrm{c}$ & $5.28 \mathrm{~cd}$ \\
$\mathrm{CV}(\%)$ & 5.67 & 3.23 & 3.06 & 3.03 & 2.98 \\
\hline
\end{tabular}

(Note: Means with similar letter (s) in column of the table do not differ significantly by DMRT at P > 5\% level).

\section{Discussion}

The research revealed that the highest plant height, number of tillers per plant, number of leaves per plant, length of leaf blade and breath of leaf blade were found on BARI Holud-1of Turmeric variety under mango tree. It may be due to that this variety may have high efficiency of using space, air, water and sunlight. It also may have high genetic vigor than other variety. The present study revealed that the plant height increased with the decrease of light levels. Plant height depends on a number of factors such as availability of required quality of water, mineral nutrients, quantity, quality and duration of light, temperature, area of growing space and genetic set-up of the plants. Hillman [6] reported that, plant grown in low light levels was found to be more apical dominant than those grown in high light environment resulting in taller plants under shade. Similar result was mentioned by [7] and [8]. In case of number of leaf per plant, the finding was in agreement with the findings of [9] who stated that, cooler temperatures promote lower number of total leaf and numbers of branches. Again in case of, length of leaf blade of turmeric due to the situation of cellular expansion and cell division of leaves under shaded condition [10] Similar result was also found by [7] for breadth of leaf blade of turmeric. The reason of maximum yield of turmeric in Agroforestry system might be that the early stage of mango tree canopy did not affect much the lower story turmeric crop whereas turmeric is a shade loving crop. Similar result was obtained by some researchers such as [11] and [12]. On the other hand crop growth is mainly affected by light and nutrient availability. Leaf litter inputs from agro-forestry trees could provide sufficient nutrients and organic matter to sustain crop growth that may improve crop yield. Similar results were observed by [13].

\section{Conclusion}

The findings of the present investigation indicate that diversification of farming 
system and growing turmeric as ground layers crops in mango tree orchard is a viable option for increasing income of farmers. One turmeric variety like BARI Holud-1 has been grown successfully as intercrops in the floor of mango tree orchard. The presence of tree canopies did not influence on the growth and yield of turmeric variety so much. Moreover, among the three turmeric varieties, BARI Holud-1 gave the better yield both in the mango based agroforestry systems as well as in sole cropping. However, the suitability of the cultivation of different turmeric variety under mango based agroforestry systems may be ranked as $\mathrm{S}_{1} \mathrm{~V}_{1}>\mathrm{S}_{2} \mathrm{~V}_{1}>\mathrm{S}_{1} \mathrm{~V}_{3}>\mathrm{S}_{2} \mathrm{~V}_{3}>\mathrm{S}_{1} \mathrm{~V}_{2}>\mathrm{S}_{2} \mathrm{~V}_{2}$. Finally it may be concluded that, BARI Holud-1 would be the best variety to be grown under mango based agroforestry.

\section{Acknowledgements}

I deeply expressed cordial thanks to Institute of Science and Technology of Hajee Mohammad Danesh Science and Technology University, Dinajpur-5200, Bangladesh for funding of this experiment.

\section{References}

[1] Purseglove, J.W. Brown, G., Green, C.L. and Robbins, S.R.J. (1981) Spices. Vol. 2. Longman Scientific and Tecnial Co. and John Wiley and Sons, Inc., New York, 457.

[2] BBS (2011) Statistical Pocket Book of Bangladesh. Bangladesh Bureau of Statistics, Ministry of Planning, Government of Peoples' Republic of Bangladesh, Dhaka.

[3] Siddique, A.B. (1995) Importance of Vegetables and Spices Production. Horticulture Research and Development Project, Dhaka.

[4] BBS (2009) Statistical Pocket Book of Bangladesh. Bangladesh Bureau of Statistics, Ministry of Planning, Government of Peoples' Republic of Bangladesh, Dhaka.

[5] Gomez, K.A. and Gomez, A.A. (1984) Statistical Procedures for Agricultural Research. 2nd Edition, John Wiley and Sons. Inc., New York, 680.

[6] Hillman, J.R. (1984) Apical Dominance, In: Wilking, M.B., Ed., Advanced plant Physiology, Pitman, London, 127-184.

[7] Sarker, M.M. (2010) Performance of Turmeric Varieties under Litchi Based Agroforestry System. MS Thesis, HSTU, Dinajpur.

[8] Garrity, D.P. (2004) Agroforestry and the Achievement of the Millenium Development Goals. Agroforestry Systems, 61, 5-17. https://doi.org/10.1023/B:AGFO.0000028986.37502.7c

[9] Schoch, P.G. (1972) Effects of Shading on Structural Characteristics of the Leaf and Yield of Fruit in Capcicum. Journal of the American Society for Horticultural Science, 97, 461-464.

[10] Benoit, G.R., Grant, W.J. and Devine, O.J. (1986) Potato Top Growth as Influenced by Day Night Temperature Differences. Agronomy Journal, 78, 264-269. https://doi.org/10.2134/agronj1986.00021962007800020010x

[11] Chaudhry, A.K. (2003) Comparative Study of Different Densities of Poplar in Wheat Based Agroforestry System in Central Punjab. M.S. Thesis, University of Agriculture, Faisalabad.

[12] Sharma, K.K., Khanna, P. and Gulati, A. (1996) The Growth and Yield of Wheat 
and Paddy Influenced by Dalbergia sisso Roxb. Boundary Plantation. India Forums, 122, 1114-1225.

[13] Lehmann, J., Gebauer, G. and Zech, W. (2002) Nitrogen Cycling Assessment in a Hedgerow Intercropping System Using $15 \mathrm{~N}$ Enrichment. Nutrient Cycling in Agroecosystems, 62, 1-9. https://doi.org/10.1023/A:1015403922358 